\title{
PENGARUH PEMBERIAN JUS BAYAM MERAH (AMARANTHUS GANGETICUS) TERHADAP PENINGKATAN KADAR HEMOGLOBIN PADA IBU HAMIL PENDERITA ANEMIA DI KLINIK SALMA KEC.PERBAUNGAN TAHUN 2020
}

\author{
Keleng Ate Ginting1, Raini Panjaitan², Andreais Boffil Cholilullah³ ${ }^{3}$ Anggi \\ Isnani Parinduri ${ }^{4}$, Resty Tri Yanti ${ }^{5}$ \\ Program Studi Gizi Fakultas Kesehatan Masyarakat \\ Institut Kesehatan Medistra Lubuk Pakam \\ Jl. Sudirman No.38 Lubuk Pakam Kec. Lubuk Pakam Kab. Deli Serdang, \\ Sumatera Utara \\ e-mail: keleng.ategtg44@gmail.com \\ DOI : https://doi.org/10.35451/jkg.v3i2.663
}

\begin{abstract}
Anemia in pregnant women greatly affects iron deficiency, because in pregnancy the need for oxygen is higher, which triggers an increase in erythropoietin production. Globally the prevalence of anemia in pregnant women worldwide is $41.8 \%$. The prevalence of anemia in pregnant women in Indonesia increased compared to 2013, in 2013 as many as $37.1 \%$ of pregnant women were anemic while in 2018 it increased to $48.9 \%$ (Riskesdas, 2018). One alternative to meet iron needs can be done by consuming vegetables, one of which is red spinach. The aim is to determine the effect of giving red spinach juice on increasing hemoglobin levels in pregnant women with anemia at the Salma Clinic, Perbaungan district in 2020. The method of pre-experimental research was one group pretest-posttest study design. The population in this study were all 28 pregnant women. January to May 2020. Sampling using purposive sampling technique. To determines the differences in the production of $\mathrm{Hb}$ levels before and after intervention in pregnant women and Hb Check. The statistical test used in this study was the paired sample $T$-Test, if the $p$ value was $\leq 0.05$. The results of the analysis test using paired sample t-test in the experimental group obtained a value of $p=0.025<(a=0.05)$, it can be concluded that the hypothesis in this study was accepted, namely the effect of giving red spinach juice on pregnant women with anemia at the Salmah Perbaungan Clinic, Serdang Bedagai Regency.
\end{abstract}

\section{Keywords: red spinach, Haemoglobin}

\section{PENDAhuluan}

Anemia pada ibu yang hamil sangat mempengaruhi defisiensi zat besi, karena pada kehamilan membutuhkan oksigen yang lebih tinggi sehingga akan meningkatkan produksi eritroprotein. Volume plasma bertambah dan eritrosit meningkat, sehingga konsentrasi hemoglobin terjadi penurunan akibat hemodilusi.

Kadar hemoglobin $<11 \mathrm{gr} / \mathrm{dl}$ pada kehamilan trimester 1 dan 3 merupakan kondisi ibu hamil mengalami anemia atau kadar hemoglobin kurang dari 10,5 $\mathrm{gr} / \mathrm{dl}$ pada masa kehamilan trimester 2 (Cunninggham, 2016). 
Jurnal Kesehatan Masyarakat \& Gizi, e-ISSN: 2655-0849

Vol. 3 No.2 Edisi November 2020 - April 2021

https://ejournal.medistra.ac.id/index.php/JKG

Received: 23 April 2021 :: Accepted: 29 April 2021 :: Published: 30 April 2021

AKI di Indonesia saat ini mencapai angka 305/100.000 kelahiran hidup masih jauh di atas target yaitu 102/100.000 kelahiran hidup di tahun 2019. Provinsi penyumbang AKI yang disebabkan oleh kehamilan, persalinan dan ibu nifas ialah Provinsi Papua yaitu $730 / 100.000$ kelahiran hidup (Kemenkes RI, 2015).

Data dari (WHO, 2010), prevalensi anemia pada ibu hamil di dunia adalah $41,8 \%$. Prevalensi anemia pada ibu hamil di Indonesia meningkat dibandingkan dengan tahun 2013 yaitu sebanyak $37,1 \%$ dan sementara pada tahun 2018 prevalensi mengalami peningkatan yaitu menjadi $48,9 \%$ (Riskesdas, 2018).

Menurut data (Riskesdas, 2018), cakupan ibu hamil yang mengonsumsi 90 butir dan memperoleh tablet tambah darah $38,1 \%$, sisanya yaitu $61,9 \%$ yang mengonsumsi di bawah 90 butir. Data tersebut berarti menunjukkan bahwa $\pm 61,9 \%$ tidak mengonsumsi tablet tambah darah sesuai anjuran.

Kebutuhan asupan zat besi tiap trimester kehamilan beda, pada kehamilan trimester awal justru kebutuhan zat besi lebih rendah dari masa sebelum hamil dikarenakan wanita tidak mengalami menstruasi selama masa kehamilan dan janin hanya sedikit membutuhkan zat besi. Pada usia kehamilan di trimester 2, akan mulai meningkat untuk kebutuhan zat besi, karena jumlah sel-sel darah merah akan bertambah. Pada trimester ketiga, sel darah merah bertambah hingga mencapai $35 \%$, sehingga kebutuhan zat besi akan meningkat sebanyak $450 \mathrm{mg}$. Sel darah merah akan lebih meningkat dikarenakan kebutuhan oksigen dari janin akan meningkat. Penyerapan zat besi dalam tubuh dapat ditingkatkan oleh senyawa-senyawa asam seperti vitamin C, suksinat kobal, asam klorida inosin, etionin. Asam akan mereduksiion zat feri menjadi fero dan dengan makanan yang tidak larut akan menghambat pembentukan zat besi (Gunawan, 2016).

Salah satu cara untuk dapat terpenuhinya zat besi dapat dilakukan dengan cara banyak mengkonsumsi sayuran-sayuran salah satunya bayam merah. Zat besi yang terkandung dalam bayam merah sangat tinggi sebesar 3,9mg/100gram (Merlina, 2016).

Bayam merah juga berfungsi melancarkan sirkulasi oksigen dalam darah. Sama seperti Vitamin A dan vitamin $C$ juga berfungsi sebagai antioksidan yang melindungi tubuh dan otak dari racun dan polusi. Vitamin $\mathrm{C}$ juga membantu dan mempercepat absorbsi zat besi untuk proses sistem imun tubuh. Selain itu, adanya vitamin B12 dan asam folat merupakan gabungan penting untuk pembentukan sel darah merah, sehingga mempengaruhi zat besi dalam darah dan akan terjadi peningkatan kadar hemoglobin (Sugiarto, 2015).

Menurut survey pendahuluan yang dilakukan di Klinik Salma Kecamatan Perbaungan tahun 2020, diketahui bahwa dari 25 ibu hamil yang memeriksakan kehamilannya diklinik terdapat 5 orang diantaranya mengeluh sering mengalami pusing, lelah, lemas dan setelah dilakukan pemeriksaan $\mathrm{Hb}$ $<11$ gram/dL. Selain itu penyebab terjadinya anemia kebanyakan ibu hamil yang kurang mengkonsumsi makanan yang mengandung zat besi seperti bayam merah. Berdasarkan uji pendahuluan yang dilakukan, peneliti tertarik untuk melakukan penelitian tentang "Pengaruh Pemberian Jus Bayam Merah terhadap peningkatan kadar Hemoglobin pada Ibu Hamil dengan Anemia di Klinik Salma Kecamatan Perbaungan tahun 2020".

\section{METODE PENELITIAN}


Jurnal Kesehatan Masyarakat \& Gizi, e-ISSN: 2655-0849

Vol. 3 No. 2 Edisi November 2020 - April 2021

https://ejournal.medistra.ac.id/index.php/JKG

Received: 23 April 2021 :: Accepted: 29 April 2021 :: Published: 30 April 2021

Jenis penelitian yang digunakan pada penelitian ini yaitu penelitian kuntitatif yaitu Quasi eksperiment dengan rancangan one-group pretestposttest design. Populasi dalam penelitain ini adalah ibu hamil penderita anemia yang berjumlah 28 orang.

Pengambilan sampel dengan menggunakan teknik purposive sampling yaitu peneliti menentukan sendiri sampel penelitian dimana sampel penelitian ini berdasarkan kriteria inklusi dan kriteria eksklusi. Untuk mengetahui perbedaan produksi kadar $\mathrm{Hb}$ sebelum dan sesudah dilakukan intervensi pada ibu hamil dan Check $\mathrm{Hb}$ dengan menggunakan alat pengukur $\mathrm{Hb}$ merk Easy touch. Pada penelitian ini menggunakan 2 kelompok kelas, yaitu kelompok intervensi (perlakuan) dan kelompok kontrol. Uji statistik yang digunakan pada penelitian ini adalah paired sampel $T$-Test, apabila $p$ value $\leq$ 0,05 maka ada pengaruh pemberian jus bayam merah terhadap peningkatan kadar hemoglobin pada ibu hamil penderita anemia.

\section{HASIL}

Tabel 1. Distribusi Karakteristik Umur Responden Ibu hamil di Klinik Salmah Perbaungan Kabupaten Serdang Bedagai

\begin{tabular}{|c|c|c|}
\hline Umur & $\begin{array}{l}\text { Frekuensi } \\
\text { (f) }\end{array}$ & $\begin{array}{c}\text { Persentase } \\
(\%)\end{array}$ \\
\hline 20 - 30 Tahun & 17 & $60.7 \%$ \\
\hline 31 - 50 Tahun & 11 & $39.3 \%$ \\
\hline Total & 28 & $100.0 \%$ \\
\hline $\begin{array}{l}\text { Berdasar } \\
\text { didapatkan dis } \\
30 \text { tahun seba } \\
\text { usia } 31-50 \text { ta } \\
(39,3 \%) \text {. Dari } \\
\text { bahwa mayo } \\
\text { dengan usia } 2\end{array}$ & $\begin{array}{l}\text { n Tabel } \\
\text { busi freku } \\
\text { ak } 17 \text { orar } \\
\text { un sebany } \\
\text { abel diatas } \\
\text { as umur } \\
30 \text { tahun }\end{array}$ & $\begin{array}{l}\text { 1. maka } \\
\text { si usia } 20- \\
(60,7 \%) \text {, } \\
11 \text { orang } \\
\text { nenyatakan } \\
\text { responden } \\
\text { ebanyak } 17\end{array}$ \\
\hline
\end{tabular}

Tabel 2. Kadar Hemoglobin ibu hamil penderita Anemia di Klinik Salmah Perbaungan Kabupaten Serdang Bedagai

\begin{tabular}{ccc}
\hline \multicolumn{3}{c}{ Pre Eksperimen } \\
\hline $\begin{array}{c}\text { Jenis } \\
\text { anemia }\end{array}$ & $\begin{array}{c}\text { Frekueensi } \\
(\mathbf{f})\end{array}$ & Persentase \\
\hline $\begin{array}{c}\text { Anemia } \\
\text { Ringan }\end{array}$ & 0 & $0.00 \%$ \\
\hline $\begin{array}{c}\text { Anemia } \\
\text { Sedang }\end{array}$ & 10 & $35.7 \%$ \\
\hline $\begin{array}{c}\text { Anemia } \\
\text { Berat }\end{array}$ & 18 & $64.3 \%$ \\
\hline Total & $\mathbf{2 8}$ & $\mathbf{1 0 0 . 0} \%$ \\
\hline
\end{tabular}

Dari tabel 2. dapat diketahui bahwa sebelum dilakukan pemberian jus bayam merah tidak ada yang dinyatakan Anemia Ringan, yang dinyatakan anemia sedang sebanyak 10 orang $(35,7 \%)$, dari tabel diatas menyatakan mayoritas responden menyatakan anemia berat sebanyak 18 orang $(64,3 \%)$. 
Jurnal Kesehatan Masyarakat \& Gizi, e-ISSN: 2655-0849

Vol. 3 No.2 Edisi November 2020 - April 2021

https://ejournal.medistra.ac.id/index.php/JKG

Received: 23 April 2021 :: Accepted: 29 April 2021 :: Published: 30 April 2021

Tabel 3. Kadar hemoglobin Sesudah Dilakukan Pemberian jus bayam merah terhadap ibu hamil penderita anemia di klinik salmah perbaungan kabupaten serdang bedagai

\begin{tabular}{ccc}
\hline \multicolumn{3}{c}{ Post Eksperimen } \\
\hline $\begin{array}{c}\text { Jenis } \\
\text { anemia }\end{array}$ & $\begin{array}{c}\text { Frekueensi } \\
\text { (f) }\end{array}$ & Persentase \\
\hline $\begin{array}{c}\text { Anemia } \\
\text { Ringan }\end{array}$ & 16 & $57.1 \%$ \\
\hline $\begin{array}{c}\text { Anemia } \\
\text { Sedang }\end{array}$ & 9 & $32.1 \%$ \\
\hline $\begin{array}{c}\text { Anemia } \\
\text { Berat }\end{array}$ & 3 & $10.7 \%$ \\
\hline Total & $\mathbf{2 8}$ & $\mathbf{1 0 0 . 0} \%$ \\
\hline
\end{tabular}

Dari tabel 3. dapat diketahui bahwa sesudah dilakukan pemberian jus bayam merah yang menyatakan anemia Ringan sebanyak 16 orang $(57,1$ $\%)$,yang menyatakan anemia sedang sebanyak 9 orang $(32,1 \%)$, yang menyatakan mayoritas responden menyatakan anemia berat sebanyak 3 orang $(10,7 \%)$. Dari tabel diatas mayoritas menyatakan anemia ringan sebanyak 16 orang $(57,1 \%)$.

Tabel 4. Pengaruh Pemberian jus bayam merah terhadap ibu hamil penderita anemia di klinik Salmah Perbaungan Kabupaten Serdang Bedagai

\begin{tabular}{ccc}
\hline $\begin{array}{c}\text { Perubahan } \\
\text { Kadar } \\
\text { Hemoglobin }\end{array}$ & \multicolumn{2}{c}{ Paired Sample T-Test } \\
\cline { 2 - 3 } & & \\
\hline
\end{tabular}

Eksperimen -

$\begin{array}{llll}\text { Post } & 0.393 & 0.875 & 0.025\end{array}$

Eksperimen

Dari tabel 4. didapat kan bahwa hasil uji statistik menggunakan paired sample t-test pada kelompok eksperimen didapatkan nila $\mathrm{p}=0.025<$ $(a=0.05)$ maka dapat disimpulkan bahwa hipotesa pada penelitian ini diterima yaitu Pengaruh Pemberian Jus bayam merah Terhadap ibu hamil penderita Anemia di Klinik Salmah Perbaungan Kabupaten Serdang Bedagai.

\section{PEMBAHASAN}

Berdasarkan hasil analisis penelitian menunjukkan bahwa pengaruh pemberian jus bayam merah terhadap peningkatan kadar $\mathrm{Hb}$ pada ibu hamil rata-rata kadar hemoglobin responden sebelum pemberian jus bayam merah adalah 9.0308 dengan Std. Deviasi 0.81587, sedangkan sesudah pemberian jus bayam merah adalah 10,261 dengan Std. Deviasi 0,8520 . Terlihat nilai mean perbedaan antara sebelum pemberian dan setelah pemberian jus bayam merah adalah 1,2308 dengan standar deviasi 0,4715. Hasil analisis data dengan uji paired sample $t$ test didapatkan nilai 0,000 yang artinya $<0,05$ maka hal in ada pengaruh pemberian jus bayam merah terhadap perubahan kadar haemoglobin ibu hamil anemia.

Hasil penelitian ini sejalan dengan penelitian yang dilakukan oleh Rohmatika et al (2015) di Puskemas Gambirsari Surakarta selama 7 hari yang menunjukkan hasil adanyan peningkatan kadar $\mathrm{Hb}$ yang signifikan setelah konsumsi ekstrak bayam merah dengan uji statistik nilai signifikansi lebih kecil dari alpa p 0,000 ( $p<0,05)$ (Astawan, 2008).

Hasil penelitian ini juga sejalan dengan penelitian serupa tentang manfaat bayam merah yang diteliti oleh Ristin Setiyani (2012). Penelitian yang berjudul "Manfaat Bayam Merah" diperoleh hasil bahwa bayam merah berguna untuk mengobati penyakit kurang darah. 
Jurnal Kesehatan Masyarakat \& Gizi, e-ISSN: 2655-0849

Vol. 3 No.2 Edisi November 2020 - April 2021

https://ejournal.medistra.ac.id/index.php/JKG

Received: 23 April 2021 :: Accepted: 29 April 2021 :: Published: 30 April 2021

\section{KESIMPULAN}

Berdasarkan dari hasil penelitian dan analisis data yang telah dilakukan telah diuraikan sebelumnya mengenai " Pengaruh Pemberian Jus Bayam Merah Terhadap Peningkatan kadar Hemoglobin Ibu Hamil penderita anemia di Klinik Salmah Perbaungan " dapat disimpulkan bahwa :

1. Mayoritas Anemia kehamilan tanpa pemberian jus bayam di Klinik Salmah Perbaungan adalah, Anemia berat (64.3\%) dan Anemia sedang (35.7\%)

2. Mayoritas Anemia Kehamilan dengan pemberian jus bayam, di Klinik Salmah Perbaungan adalah, Anemia ringan (57.1\%), berdasarkan tingkat penaikan kadar hb kehamilan $(p=0.05)$

3. Dari hasil penelitian yang dilakukan terhadap 28 responden, ternyata ada pengaruh yang signifikan antara dengan pemberian jus bayam merah terhadap peningkatan kadar hemoglobin ibu Hamil penderita anemia dengan nilai $\mathrm{p}$ value $=0.025<0.005$

\section{DAFTAR PUSTAKA}

Almatsier, 2009. Prinsip Dasar Ilmu Gizi . Jakarta : PT Gramedia Pustaka

Arikunto, Suharsini. 2010. Prosedur Penelitian Suatu Pendekatan Praktik. Jakarta: Rineka Cipta

Cunninggham, 2016. Obstetri Williams Edisi 21. Jakarta : EGC

Fikawaki, 2015. Gizi Ibu dan Anak, Depok : PT RajaGrafindo Persada

Gandy, 2016. Gizi dan Dietetika Edisi 2. Jakarta : EGC
Gibney, 2009. Gizi Kesehatan Masyarakat. Jakarta :EGC

Hidayat, Alimul Aziz. 2008. Keterampilan Dasar praktik Klinik Untuk Kebidanan, Jakarta: Salemba Medika

Irianto, 2016. Gizi Seimbang dama kesehatan Reproduksi (Balanced Nutririon In Reproductive Health). Bandung : Penerbit Alafabeta

Khomsan, Ali, MS. Prof. Dr. Ir. 2011. Terapi Jus Untuk Rematik dan Asam Urat, Bandung: Sehat Keluarga

Kusmiyati, Yuni, S. T. dkk 2009. Perawatan Ibu Hamil, Yogyakarta: FitramayaManuaba Ida Bagus Gede. Prof,dr dkk (2010), Ilmu Kebidanan, Penyakit Kandungan, dan KB. Jakarta: EGC

Riset Kesehatan Dasar (Rikesdes), 2018. Badan Penelitian dan pengembangan Kesehatan Kementrian RI tahun 2018. http//www.depkes.go.id/resourc es/download/infoterkini/materi rakorpop2018/Hasil\%20Rikesde s\%202018.pdf- Diakes Agustus 2018.

Sulihandri, 2013. Panduan Terapi Sayuran. Jakarta Selatan : PT. Agro Media Pustaka

Thomas. 2008. Tanaman Obat Tradisional, Yogyakarta: KANISUS (Anggota IKAPI) 